NASA/TM-2000-209891, Vol. 3

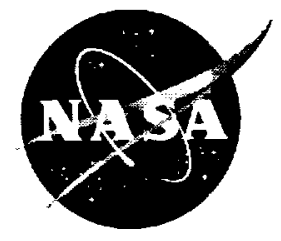

Technical Report Series on the Boreal Ecosystem-Atmosphere Study (BOREAS)

Forrest G. Hall and David E. Knapp, Editors

Volume 3

BOREAS AFM-2 Wyoming King Air 1994 Aircraft Sounding Data

R. D. Kelly

National Aeronautics and

Space Administration

Goddard Space Flight Center

Greenbelt, Maryland 20771 
The NASA STI Program Office ... in Profile

Since its founding, NASA has been dedicated to the advancement of aeronautics and space science. The NASA Scientific and Technical Information (STI) Program Office plays a key part in helping NASA maintain this important role.

The NASA STI Program Office is operated by Langley Research Center, the lead center for NASA's scientific and technical information. The NASA STI Program Office provides access to the NASA STI Database, the largest collection of aeronautical and space science STI in the world. The Program Office is also NASA's institutional mechanism for disseminating the results of its research and development activities. These results are published by NASA in the NASA STI Report Series, which includes the following report types:

- TECHNICAL PUBLICATION. Reports of completed research or a major significant phase of research that present the results of NASA programs and include extensive data or theoretical analysis. Includes compilations of significant scientific and technical data and information deemed to be of continuing reference value. NASA's counterpart of peer-reviewed formal professional papers but has less stringent limitations on manuscript length and extent of graphic presentations.

- TECHNICAL MEMORANDUM. Scientific and technical findings that are preliminary or of specialized interest, e.g., quick release reports, working papers, and bibliographies that contain minimal annotation. Does not contain extensive analysis.

- CONTRACTOR REPORT. Scientific and technical findings by NASA-sponsored contractors and grantees.
- CONFERENCE PUBLICATION. Collected papers from scientific and technical conferences, symposia, seminars, or other meetings sponsored or cosponsored by NASA.

- SPECIAL PUBLICATION. Scientific, technical, or historical information from NASA programs, projects, and mission, often concerned with subjects having substantial public interest.

- TECHNICAL TRANSLATION. English-language translations of foreign scientific and technical material pertinent to NASA's mission.

Specialized services that complement the STI Program Office's diverse offerings include creating custom thesauri, building customized databases, organizing and publishing research results ... even providing videos.

For more information about the NASA STI Program Office, see the following:

- Access the NASA STI Program Home Page at http://www.sti.nasa.gov/STI-homepage.html

- E-mail your question via the Internet to help@sti.nasa.gov

- Fax your question to the NASA Access Help Desk at (301) 621-0134

- Telephone the NASA Access Help Desk at (301) 621-0390

- Write to:

NASA Access Help Desk

NASA Center for AeroSpace Information

7121 Standard Drive

Hanover, MD 21076-1320 
NASA/TM-2000-209891, Vol. 3

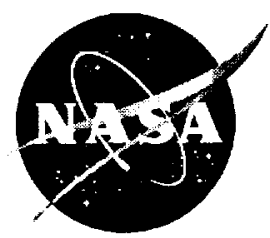

Technical Report Series on the Boreal Ecosystem-Atmosphere Study (BOREAS)

Forrest G. Hall and David E. Knapp, Editors

\section{Volume 3}

\section{BOREAS AFM-2 Wyoming King Air 1994 Aircraft Sounding Data}

Robert D. Kelly, University of Wyoming

National Aeronautics and

Space Administration

Goddard Space Flight Center

Greenbelt, Maryland 20771 
Available from:

NASA Center for AeroSpace Information

7121 Standard Drive

Hanover, MD 21076-1320

Price Code: A17
National Technical Information Service 5285 Port Royal Road

Springfield, VA 22161 


\title{
BOREAS AFM-2 Wyoming King Air 1994 Aircraft Sounding Data
}

\author{
Robert D. Kelly
}

\section{Summary}

The BOREAS AFM-2 team used the University of Wyoming King Air aircraft during IFCs 1, 2, and 3 in 1994 to collected pass-by-pass fluxes (and many other statistics) for the large number of level (constant altitude), straight-line passes used in a variety of flight patterns over the SSA and NSA and areas along the transect between these study areas. The data described here form a second set, namely soundings that were incorporated into nearly every research flight by the King Air in 1994. These soundings generally went from near the surface to above the inversion layer. Most were flown immediately after takeoff or immediately after finishing the last flux pattern of that particular day's flights. The parameters that were measured include wind direction, wind speed, west wind component (u), south wind component (v), static pressure, air dry bulb temperature, potential temperature, dewpoint, temperature, water vapor mixing ratio, and $\mathrm{CO}_{2}$ concentration. Data on the aircraft's location, attitude, and altitude during data collection are also provided. These data are stored in tabular ASCII files.

\section{Table of Contents}
1) Data Set Overview
2) Investigator(s)
3) Theory of Measurements
4) Equipment
5) Data Acquisition Methods
6) Observations
7) Data Description
8) Data Organization
9) Data Manipulations
10) Errors
11) Notes
12) Application of the Data Set
13) Future Modifications and Plans
14) Software
15) Data Access
16) Output Products and Availability
17) References
18) Glossary of Terms
19) List of Acronyms
20) Document Information

\section{Data Set Overview}

\subsection{Data Set Identification \\ BOREAS AFM-02 Wyoming King Air 1994 Aircraft Sounding Data}

\subsection{Data Set Introduction}

The BOReal Ecosystem-Atmosphere Study (BOREAS) Airborne Fluxes and Meteorology (AFM)-02 team used the University of Wyoming King Air aircraft during Intensive Field Campaigns (IFCs) 1, 2, and 3 in 1994 to collected pass-by-pass fluxes (and many other statistics) for the large number of level (constant altitude), straight-line passes used in a variety of flight pattems. The data 
described here form a second set, namely soundings that were incorporated into nearly every research flight by the King Air in 1994. These soundings generally went from near the surface to above the inversion layer. Most were flown immediately after takeoff or immediately after finishing the last flux pattern of that particular day's flights. The parameters that were measured include wind direction, wind speed, west wind component ( $u$ ), south wind component (v), static pressure, air dry bulb temperature, potential temperature, dewpoint, temperature, water vapor mixing ratio, and $\mathrm{CO}_{2}$ concentration. Data on the aircraft's location, attitude, and altitude during data collection are also provided. These data are stored in tabular American Standard Code for Information Interchange (ASCII) files.

\subsection{Objective/Purpose}

The objective of this data set is to add to the set of soundings represented by the network of rawinsondes launched during the project.

\subsection{Summary of Parameters}

The following is a simple list of the variables archived for each sounding by the King Air. Section 7 defines the variables and their origins in detail. Those variables flagged $\left({ }^{*}\right)$ were not measured by the King Air.

\section{VARIABLES:}

- BOREAS aircraft i.d.

- 20-character aircraft descriptor

- Date

- BOREAS mission designator

- $\quad$ Start time, Greenwich Mean Time (GMT)

- $\quad$ End time

- Starting latitude

- End latitude

- $\quad$ Starting longitude

- End longitude

- $\quad$ Starting BOREAS Information System (BORIS) grid E

- $\quad$ End BORIS grid E

- $\quad$ Starting BORIS grid N

- $\quad$ End BORIS grid $\mathrm{N}$

There is one line of data for each second of sounding data. For data collected at rates greater than $1 \mathrm{~Hz}$, the entry is a 1-second average:

- Time, GMT

- Latitude

- Longitude

- Pressure altitude

- Radar altitude

- Aircraft heading

- Wind direction

- Wind speed

- West wind component, u

- $\quad$ South wind component, $v$

- Static pressure

- Air dry bulb temperature

- Potential temperature

- Dewpoint temperature

- Water vapor mixing ratio

- $\mathrm{CO} 2$ concentration

- Ozone concentration ** 


\subsection{Discussion}

The King Air was flown in all three IFCs in 1994. These archived sounding data were collected primarily over the two BOREAS study areas and occasionally on regional runs between the Southem Study Area (SSA) and the Northern Study Area (NSA). The high-rate data from which all these variables were computed were not submitted to BORIS. If required, they may be acquired from the University of Wyoming directly.

\subsection{Related Data Sets}

Related data sets include the King Air flux data for BOREAS-94 and the flux and/or sounding archives from the other three flux aircraft (AFM-01, AFM-03, AFM-04). Other related data sets include soundings from rawinsondes (AFM-05) launched during corresponding dates.

BOREAS AFM-01 NOAA/ATDD Long-EZ 1994 Aircraft Flux Data over the SSA

BOREAS AFM-02 Wyoming King Air 1994 Aircraft Flux and Moving Window Data

BOREAS AFM-03 NCAR Electra 1994 Aircraft Flux and Moving Window Data

BOREAS AFM-03 NCAR Electra 1994 Aircraft Sounding Data

BOREAS AFM-04 NRC Twin Otter Aircraft Flux Data

BOREAS AFM-04 NRC Twin Otter Aircraft Sounding Data

BOREAS AFM-05 Level-1 Upper Air Network Data

BOREAS AFM-05 Level-2 Upper Air Network Standard Pressure Level Data

\section{Investigator(s)}

\subsection{Investigator(s) Name and Title}

Dr. Robert D. Kelly, Associate Professor

Dept. of Atmospheric Science

University of Wyoming

P.O. Box 3038

Laramie, WY 82071-3038

\subsection{Title of Investigation}

Airbome Investigation of Biosphere-Atmosphere Interactions over the Boreal Forest

\subsection{Contact Information}

\section{Contact 1:}

Robert D. Kelly

Department of Atmospheric Sciences

P.O. Box 3038 Univ. Station

Laramie, WY 82071-3038

(307) 766-5955

(307) 766-2635 (fax)

rkelly@grizzly.uwyo.edu

\section{Contact 2:}

David Knapp

Raytheon ITSS

NASA GSFC

Code 923.4

Greenbelt, MD 20771

(301) 286-1424

(301) 286-0239 (fax)

David.Knapp@gsfc.nasa.gov 


\section{Theory of Measurements}

The theory and practice of measuring atmospheric variables from a moving, aircraft platform have been discussed by many researchers. A series of introductory monographs addressing those topics may be found in Lenschow (1986).

Briefly, the aircraft uses gust sensors to measure the 3-D air motion relative to the aircraft and a combination of an inertial platform, accelerometers, and (more recently) a satellite-based global positioning system (GPS) to measure the motion of the aircraft relative to Earth. These data are combined to determine aircraft position and the Earth-relative 3-D winds. Scalar quantities, including static pressure, temperature, water vapor mixing ratio, and $\mathrm{CO}_{2}$ mixing ratio are also measured with fast-response, aircraft-mounted sensors.

\section{Equipment}

\subsection{Sensor/Instrument Description}

\section{Table of University of Wyoming King Air Instruments}

\section{Variable}

Hi-rate temperature

Dewpoint temperature

Water vapor mix ratio

$\mathrm{CO}_{2}$ mix ratio

Magnetic heading

Static pressure

Static pressure

Geometric Altitude

Geometric Altitude

Total pressure

Azimuth VOR

Distance DME

Latitude/longtitude

Latitude/longtitude

Ground velocity

Vertical velocity

Pitch/roll

Platform heading

Flow angle

Vertical acceleration

Rate of climb

Engine torque

Liquid Water Content

Liquid Water Content

Cloud drops

\section{Radiation:}

Upwelling Shortwave

(0.3-3 microns)

Downwelling Shortwave

\section{Instrument}

Rosemount housing, fast-response thermistor (design by Friehe, UCI)

Cambridge Model 1373C

LICOR 6262 IR spectrometer

LICOR 6262 IR spectrometer

King KPI553/Sperry C14-43

Rosemount 1201FAIB1A

Rosemount 1501

Stewart Warner APN159

King KPA 405

Rosemount 831CPX

King KNR615 VOR

King KNR705A DME

Tremble 2000 GPS

Honeywell Laseref SM

Honeywell Laseref SM

Honeywell Laseref SM

Honeywell Laseref SM

Honeywell Laseref SM

Rosemount 858AJ/831CPX

Humphrey SA090502I

Rosemount 1241A4BCDE

In-house CSIRO hot wire

Bacharach LWH

PMS FSSP

Eppley Pyranometer

Eppley Pyranometer

\begin{tabular}{|c|c|}
\hline Accuracy & Resolution \\
\hline $0.50 \mathrm{C}$ & $0.01 \mathrm{C}$ \\
\hline $1.0 \mathrm{C},>0 \mathrm{C}$ & $0.006 \mathrm{C}$ \\
\hline $1 \%$ of reading & $0.001 \mathrm{~g} / \mathrm{kg}$ \\
\hline$+/-1 \mathrm{ppm}$ at $.01 \mathrm{ppm}$ & 350 ppm \\
\hline 1 degree & 0.02 degree \\
\hline $0.5 \mathrm{mb}$ & $0.06 \mathrm{mb}$ \\
\hline $0.5 \mathrm{mb}$ & $0.003 \mathrm{mb}$ \\
\hline $1 \%$ reading & $0.24 \mathrm{ft}$ \\
\hline $3 \%<500 \mathrm{ft}$ & $0.48 \mathrm{ft}$ \\
\hline \multicolumn{2}{|l|}{$6 \%>500 \mathrm{ft}$} \\
\hline $2 \mathrm{mb}$ & $0.005 \mathrm{mb}$ \\
\hline 1 degree & 0.02 degree \\
\hline 0.2 nautical miles & 0.1 nautical mile \\
\hline $100 \mathrm{~m}$ & 0.000172 degree \\
\hline $0.8 \mathrm{~nm} / \mathrm{hr} \mathrm{drift}$ & 0.000172 degree \\
\hline $13.5 \mathrm{ft} / \mathrm{s}$ & $0.0039 \mathrm{kts}$ \\
\hline $0.5 \mathrm{ft} / \mathrm{s}$ & $0.03215 \mathrm{ft} / \mathrm{min}$ \\
\hline 0.05 degree & 0.000172 degree \\
\hline 0.2 degree & 0.000172 degree \\
\hline 0.2 degree & 0.00375 degree \\
\hline $0.002 \mathrm{~g}$ & $0.0001 \mathrm{~g}$ \\
\hline $1 \%,<15000 \mathrm{ft}$ & $0.004 \mathrm{~m} / \mathrm{s}$ \\
\hline \multicolumn{2}{|l|}{$2 \%,>25000 \mathrm{ft}$} \\
\hline- & $0.2 \mathrm{ft}-\mathrm{lbf}$ \\
\hline $0.2 \mathrm{~g} / \mathrm{m}^{3}$ & $0.0003 \mathrm{~g} / \mathrm{m}^{3}$ \\
\hline $0.2 \mathrm{~g} / \mathrm{m}^{3}$ & $0.0002 \mathrm{~g} / \mathrm{m}^{3}$ \\
\hline 3 micron & 3 micron \\
\hline
\end{tabular}

$5 \mathrm{~W} / \mathrm{m}^{2} \quad 1 \mathrm{~W} / \mathrm{m}^{2}$

$5 \mathrm{~W} / \mathrm{m}^{2} \quad 1 \mathrm{~W} / \mathrm{m}^{2}$ 
(0.3-3 microns)

Upwelling IR

(4-50 microns)

Downwelling IR

(4-50 microns)

Eppley Pyrgeometer

Eppley Pyrgeometer
$15 \mathrm{~W} / \mathrm{m}^{2}$

$15 \mathrm{~W} / \mathrm{m}^{2}$
$1 \mathrm{~W} / \mathrm{m}^{2}$

$1 \mathrm{~W} / \mathrm{m}^{2}$

\subsubsection{Collection Environment}

The data were collected at the beginning and end of each day's flights over a vertical range with varying atmospheric conditions.

\subsubsection{Source/Platform}

Platform: Beechcraft Super King Air model 200T, twin-turboprop aircraft.

\subsubsection{Source/Platform Mission Objectives}

See Section 1.4.

\subsubsection{Key Variables}

See Sections 1.4, 1.5, and 7.3.

\subsubsection{Principles of Operation}

See Section 3.

\subsubsection{Sensor/Instrument Measurement Geometry}

The gust probe was mounted at the end of the aircraft nose boom, so that the gust probe tip was about $2 \mathrm{~m}$ ahead of the nose of the aircraft. The inertial reference system (IRS) and accelerometers were mounted close to the main wing spar (close to aircraft's center of gravity). The fast-response (Friehe-type) temperature probe was mounted below the nose of the aircraft, $1.29 \mathrm{~m}$ aft from the gust probe tip. Water vapor and $\mathrm{CO}_{2}$ measurements were obtained with the LI-COR 6262 infrared absorption spectrometer. Air was drawn from the airstream above the aircraft cabin into a $12.7-\mathrm{mm}$ i.d. "snorkel" tube that faced forward, about $0.3 \mathrm{~m}$ above the fuselage skin and $4.06 \mathrm{~m}$ aft of the gust probe tip. Airflow in the snorkel tube was maintained with a high-capacity vacuum pump at $60-70$ SLPM (about $9 \mathrm{~m} / \mathrm{s}$ ), for Reynolds number about 50,000 (fully developed turbulent flow). At $1.52 \mathrm{~m}$ from the inlet, air was drawn from the center of the snorkel tube into the LI-COR through a short 6.4-mm i.d. tube, again by vacuum pump, at an average flow rate of 6-8 SLPM (also fully turbulent). As verified by flying the aircraft through a power-plant plume, there was a time delay of $0.3 \mathrm{~s}$ between the gust probe data and the LI-COR data. This delay is removed in the software at the time of data processing.

Further notes on LI-COR operation: The LI-COR 6262 was operated in "absolute" mode, in which the closed-path absorption in the sample chamber was simultaneously compared to the closed-path absorption in the reference chamber. Air in the reference chamber was circulated continuously through scrubbers that removed both water and $\mathrm{CO}_{2}$, and was circulated at a flow rate of 2 SLPM. A Cambridge chilled-mirror dewpoint hygrometer was mounted inside the cabin, drawing air from the vacuum-pump driven sample tube. All cloud and precipitation probes (PMS and liquid water content) were mounted near the wing tips of both wings.

\subsubsection{Manufacturer of Sensor/Instrument}

See table in Section 4.1

\subsection{Calibration}

The instruments were subject to calibration as follows:

- Air temperature: The manufacturer's one-time calibration was used for the Rosemount model 102, and the Friehe-type probe was then compared against the Rosemount.

- Water vapor concentration: Before each flight, the LI-COR $\mathrm{H}_{2} \mathrm{O}$ channel was calibrated by flushing the chamber with a beam-filling gas of known $\mathrm{H}_{2} \mathrm{O}$ concentration, generated with a LI-COR Model 610 dewpoint generator, with accuracy $+/-0.03{ }^{\circ} \mathrm{C}$. 
- $\mathrm{CO}_{2}$ concentration: Before each flight, the LI-COR $\mathrm{CO}_{2}$ channel was calibrated by flushing the chamber with a gas of known $\mathrm{CO}_{2}$ concentration (Source: Scott Specialty, Longmont, $\mathrm{CO}$, concentration $403.5 \mathrm{ppm}$, accurate to $4 \%$ ).

- Static pressure and gust differential pressures: The gust probe differential pressure sensors (for up-down and left-right angle of flow measurements) and absolute pressure sensor (gust probe total pressure) were calibrated at the beginning of each IFC, using the Rosemount 1501 (accurate to $0.5 \mathrm{mb}$ ).

\subsubsection{Specifications}

See table in Section 4.1.

\subsubsection{Tolerance}

See table in Section 4.1.

\subsubsection{Frequency of Calibration}

See Section 4.2.

\subsubsection{Other Calibration Information \\ None given.}

\section{Data Acquisition Methods}

Whenever possible, the soundings were executed at a relatively slow rate of ascent or descent (about 500 feet per minute). Some, however, were flown at faster rates (see data for each sounding to ascertain rate).

\section{Observations}

\subsection{Data Notes \\ None.}

\subsection{Field Notes}

None.

\section{Data Description}

\subsection{Spatial Characteristics}

\subsubsection{Spatial Coverage}

These data cover various point locations within the SSA and NSA and areas along the transect between these study areas. The majority of the data were collected over the BOREAS SSA and NSA.

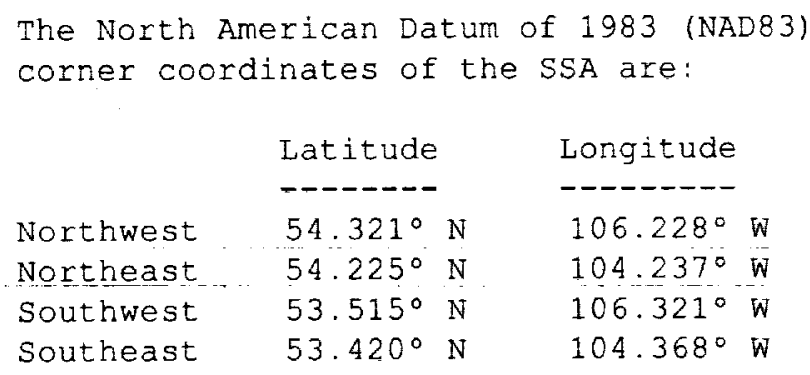




\begin{tabular}{|c|c|c|}
\hline & Latitude & Longitude \\
\hline & -------- & --------- \\
\hline Northwest & $56.249^{\circ} \mathrm{N}$ & $98.825^{\circ} \mathrm{W}$ \\
\hline Northeast & $56.083^{\circ} \mathrm{N}$ & $97.234^{\circ} \mathrm{W}$ \\
\hline Southwest & $55.542^{\circ} \mathrm{N}$ & $99.045^{\circ}$ \\
\hline Southeast & $55.379^{\circ} \mathrm{N}$ & $97.489^{\circ} \mathrm{W}$ \\
\hline
\end{tabular}

\subsubsection{Spatial Coverage Map}

Data were collected over the NSA and SSA of BOREAS, and along a transect between them. 


\subsubsection{Spatial Resolution}

Each sounding occupied a finite horizontal distance, which can be ascertained from the location information included in the data.

\subsubsection{Projection}

These data represent point measurements.

\subsubsection{Grid Description}

None.

\subsection{Temporal Characteristics}

\subsubsection{Temporal Coverage}

Times of data collection are contained in the table below. See Section 5 for flight pattern descriptions.

Table of UW King Air Research Flights for BOREAS 1994

\begin{tabular}{|c|c|c|c|c|c|}
\hline Date & Start & End & Hrs & Weather & Description and comments \\
\hline 940525 & 1745 & 2000 & 2.9 & $5-10 \% \mathrm{sct} \mathrm{cu}$ & $\mathrm{CS}, 2$ rts a-h, $300 \mathrm{agl} \mathrm{FS}$, first a-h with FE \\
\hline 940526 & 1646 & 1905 & 3.0 & $\mathrm{ci}$, small $\% \mathrm{cu}$ & GS, full rt, $300 \mathrm{agl}$ \\
\hline 940531 & 1645 & 1929 & 3.6 & $\begin{array}{l}\text { cu incr } 10-40 \% \\
\text { sharp jump } \mathrm{Zi}\end{array}$ & $\begin{array}{l}\text { FS, } 300 \mathrm{agl} \text { with FT PS, using W,E ends FK grid at } \\
200 \mathrm{agl}, 2500 \text { and } 3400 \mathrm{msl} F S \text {, a-d, } 300 \mathrm{agl} \text {, with FE }\end{array}$ \\
\hline 940601 & 630 & 1802 & 2.4 & $\begin{array}{l}\mathrm{H}, \text { ci, cist set } \mathrm{cu}< \\
1 \%\end{array}$ & LS, j-i-h-i-j, 200 agl CS, one rt d-a-d, 200 agI \\
\hline 940604 & 1616 & 1919 & 3.8 & $\begin{array}{l}\text { clr then cu incr } \\
\text { rapidly, end ove }\end{array}$ & $\begin{array}{l}\text { CS, mult passes } 200 \mathrm{agl}, 3000 \mathrm{msl} \mathrm{FS,} \mathrm{d-a,} 200 \mathrm{agl} \text {, } \\
\text { with FL }\end{array}$ \\
\hline 940606 & 1546 & 1809 & 3.1 & $\mathrm{cu}<5 \%$ & LS, mult h-i-j, 200 agl-2900 msl \\
\hline \multirow[t]{2}{*}{940607} & 1447 & 1649 & 4.8 & clr entire pattern & RT, a-h-k-l-m, $200 \mathrm{agl}$ \\
\hline & 1649 & 1904 & & clr entire pattern & $\mathrm{GN}$, full $\mathrm{rt}$, all $300 \mathrm{agl}, \mathrm{EW}$ lines \\
\hline 940608 & 1520 & 1742 & 2.9 & clr & $\begin{array}{l}\mathrm{LN} \text {, mult t-o at } 200 \mathrm{agl}, 2100 \mathrm{msl} \mathrm{FN}, \mathrm{m}-\mathrm{o}, 300 \mathrm{agl} \\
\text { with FT }\end{array}$ \\
\hline 940610 & 1642 & 1901 & 3.0 & sct ci, $\mathrm{K}$ all sky & $\mathrm{GN}$, full $\mathrm{rt}, 200 \mathrm{agl}$, NS lines \\
\hline 940611 & 1646 & 1844 & 2.6 & $\mathrm{~K}, \mathrm{cu}$ to $80 \%, \mathrm{RW}$ - & RT, o-m-l-k-h-a, $200 \mathrm{agl}$ \\
\hline 940720 & 1656 & 2044 & 4.4 & $\mathrm{H}, \mathrm{K}, \mathrm{cu} 10-50 \%$ & $\begin{array}{l}\text { CS, a-d, } 300 \text { agl to } 4800 \mathrm{msl} \text { (co-ord with FE) FS, } \\
\text { two a-d, } 300 \text { agl with FE }\end{array}$ \\
\hline 940721 & 1652 & 1905 & 3.0 & $\mathrm{clr} ?$ & $\begin{array}{l}\text { GS, full rt, } 200 \mathrm{agl} \text {, NS lines FS, one run SW of grid } \\
\text { with FT }\end{array}$ \\
\hline 940723 & 1528 & 1800 & 3.2 & $\mathrm{clr}$, incr to $20 \% \mathrm{cu}$ & $\mathrm{CS}$, mult a-d at $200 \mathrm{agl}, 3500 \mathrm{msI}$ \\
\hline 940724 & 1655 & 1943 & 3.4 & clr over site & $\mathrm{GS}$, full $\mathrm{rt}, 200 \mathrm{agl}$, EW lines \\
\hline
\end{tabular}




\begin{tabular}{|c|c|c|c|c|c|}
\hline Date & Start & End & Hrs & Weather & Description and comments \\
\hline 940725 & 1519 & 1753 & 3.2 & clr & $\mathrm{CS}$, mult a-d at $200 \mathrm{agl}, 3000 \mathrm{msl}$ \\
\hline 940726 & 1628 & 1832 & 2.7 & $\mathrm{~K}, \mathrm{ci}$ & $\mathrm{RT}, \mathrm{a}-\mathrm{h}-\mathrm{k}-\mathrm{l}-\mathrm{m}-\mathrm{o}, 200 \mathrm{agl}$ \\
\hline 940727 & 1609 & 1909 & 4.3 & $\mathrm{~K}$, altocu, cu & $\begin{array}{l}\text { GN, full rt } 200 \text { agl, NS lines TN (mult) at radar, } \\
500-1000 \text { agl }\end{array}$ \\
\hline 940728 & 1620 & 1810 & 2.6 & $\mathrm{~K}, \mathrm{ci}$ & $\begin{array}{l}\mathrm{HN}(\mathrm{GN}) \text { time-centered m-o, } 200 \mathrm{agl}, 1800 \text { and } 2700 \\
\mathrm{msl}\end{array}$ \\
\hline 940731 & 1550 & 1859 & 3.7 & $\mathrm{~K}$, clr above & GN \\
\hline 940831 & 1720 & 1938 & 2.9 & $\mathrm{~K}, \mathrm{cu}<1$ to $40 \%$ & GN, full $\mathrm{rt}, 200 \mathrm{agl}, \mathrm{EW}$ lines \\
\hline 940901 & 1550 & 1717 & 1.9 & clr above $\mathrm{K}$ & $\begin{array}{l}\text { FN, rt } 200 \mathrm{agl} \text {, with FT FN, rt } 200 \mathrm{agl} \text {, diff TAS than } \\
\text { FT LN, o-m-o-m-o, } 200 \mathrm{agl}\end{array}$ \\
\hline 940903 & 1548 & 1811 & 3.0 & ci, K, cu $0-10 \%$ & GN, full rt, 200 agl, EW lines \\
\hline 940906 & 1605 & 1833 & 2.9 & cu $20-80 \%$ & $\mathrm{GN}$, full $\mathrm{rt}, 200 \mathrm{agl}, \mathrm{NS}$ lines \\
\hline 940908 & 1606 & 1823 & 2.8 & acu, ci, cist, ci ovc & RT, o-m-l-k-h-a, $200 \mathrm{agl}$ \\
\hline 940909 & 1940 & 2131 & 2.7 & $c i$, cist thinning & $\begin{array}{l}\text { CS, mult } 200 \text { agl- } 2600 \mathrm{msl} \text {, with FE FS, } 300 \mathrm{agl} \text {, } \\
\text { with FE }\end{array}$ \\
\hline 940912 & 1735 & 2004 & 3.6 & cu incr $0-30 \%$ & $\mathrm{CS}, 3 \mathrm{rts}$, all $200 \mathrm{agl} \mathrm{Test}=3 \mathrm{rt}$ over OA area of CS \\
\hline 940913 & 1645 & 1905 & 3.4 & clr, then cist and ci & $\begin{array}{l}\text { GS, full } \mathrm{rt}, 200 \mathrm{agl} \text {, EW lines Test }=\text { wind "L" at } 8500 \\
\text { msl }\end{array}$ \\
\hline \multirow[t]{2}{*}{940916} & 1653 & 1914 & 4.8 & clr & GS, full rt, NS lines, $200 \mathrm{agl}$ \\
\hline & 1925 & 2053 & 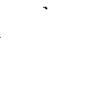 & clr then $<5 \%$ cu & $\begin{array}{l}\text { CS, d-a mult Ivls, with FE FS, second a-d with FE, } \\
600 \text { agl }\end{array}$ \\
\hline 940917 & 1712 & 1902 & 2.4 & clr, thin ci to W & $\begin{array}{l}\text { FS, one end }=\mathrm{a}, 200 \mathrm{agl} \text {, with FT CS, a-d, two rts, } 200 \\
\text { agl }\end{array}$ \\
\hline
\end{tabular}

Abbreviations used for flight patterns:

ID Description (second letter denotes NSA or SSA).

CS Candle Lake runs, SSA only, usually along path a-d.

FS, FN Flights of two (intercomparison runs), various locns.

GS, GN Grid patterns. Sequence of 9 evenly spaced, parallel

flight lines, covering a $32-\mathrm{x} 32-\mathrm{km}$ square area (King Air),

with lines oriented either east-west or north-south.

HS, HN Stack patterns.

LS, LN Transects of intermediate length (e.g., $100 \mathrm{~km}$ ).

PS,PN Budget box pattern (see Betts et al., 1990b).

RT Regional transect. For King Air, route used in

transit between NSA and SSA. Coincides with Electra RTs.

TS, TN Site-specific run at a TF (tower flux) site. 


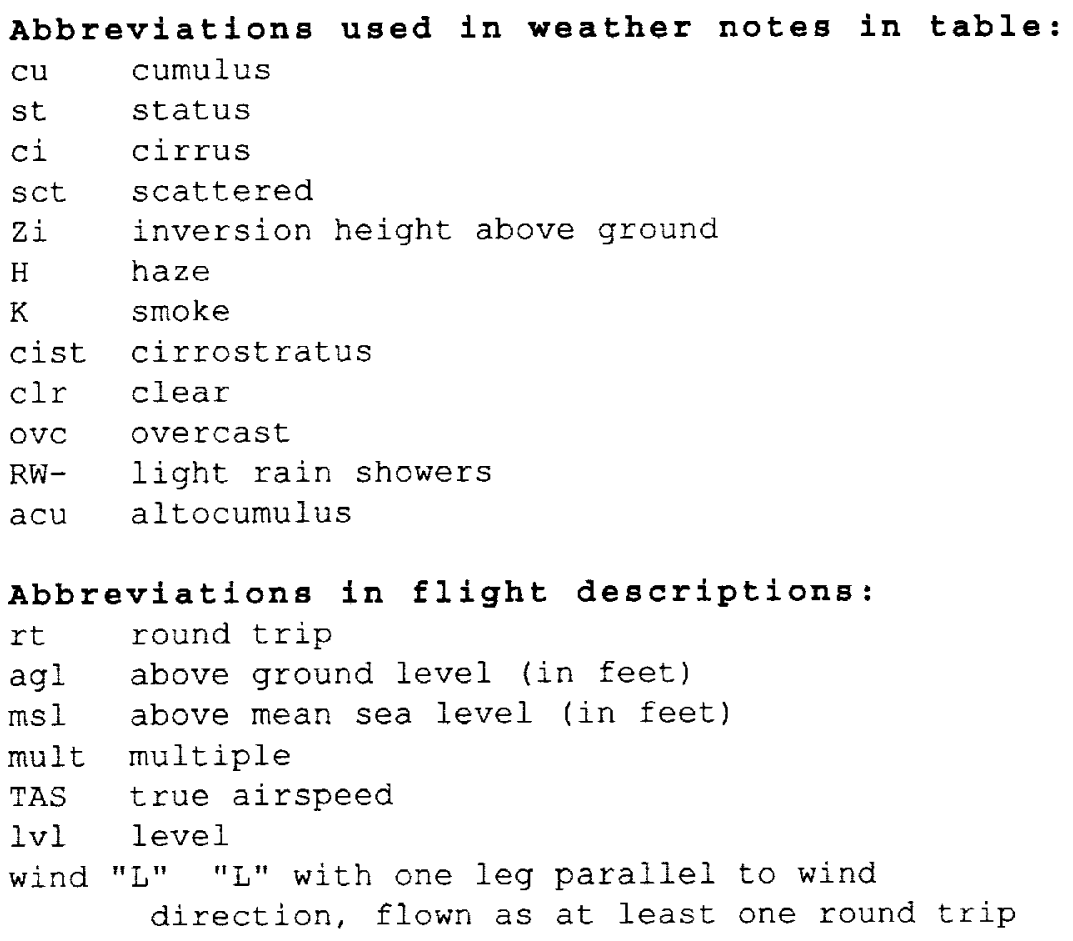

\subsubsection{Temporal Coverage Map}

None.

\subsubsection{Temporal Resolution}

See Section 7.2.1. Also, each archived data entry contains the time for the sounding being summarized.

\subsection{Data Characteristics}

\subsubsection{Parameter/Variable}

The parameters contained in the data files on the CD-ROM are:

Column Name

SPATIAL_COVERAGE
DATE_OBS
TIME
FLUX_MISSION_DESIGNATOR
LATITUDE
LONGITUDE
BOREAS_X
BOREAS_Y
BRESS_ALT
RADAR_ALT
HEADING
WIND_DIR
WIND_SPEED
U_COMPNT_WIND_VELOC
V_COMPNT_WIND_VELOC




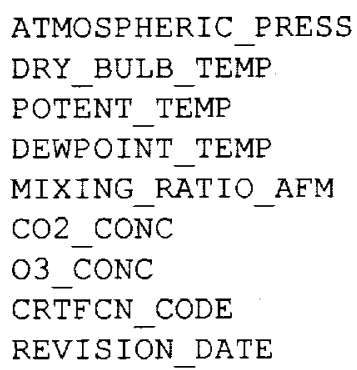

\subsubsection{Variable Description/Definition}

The descriptions of the parameters contained in the data files on the CD-ROM are:

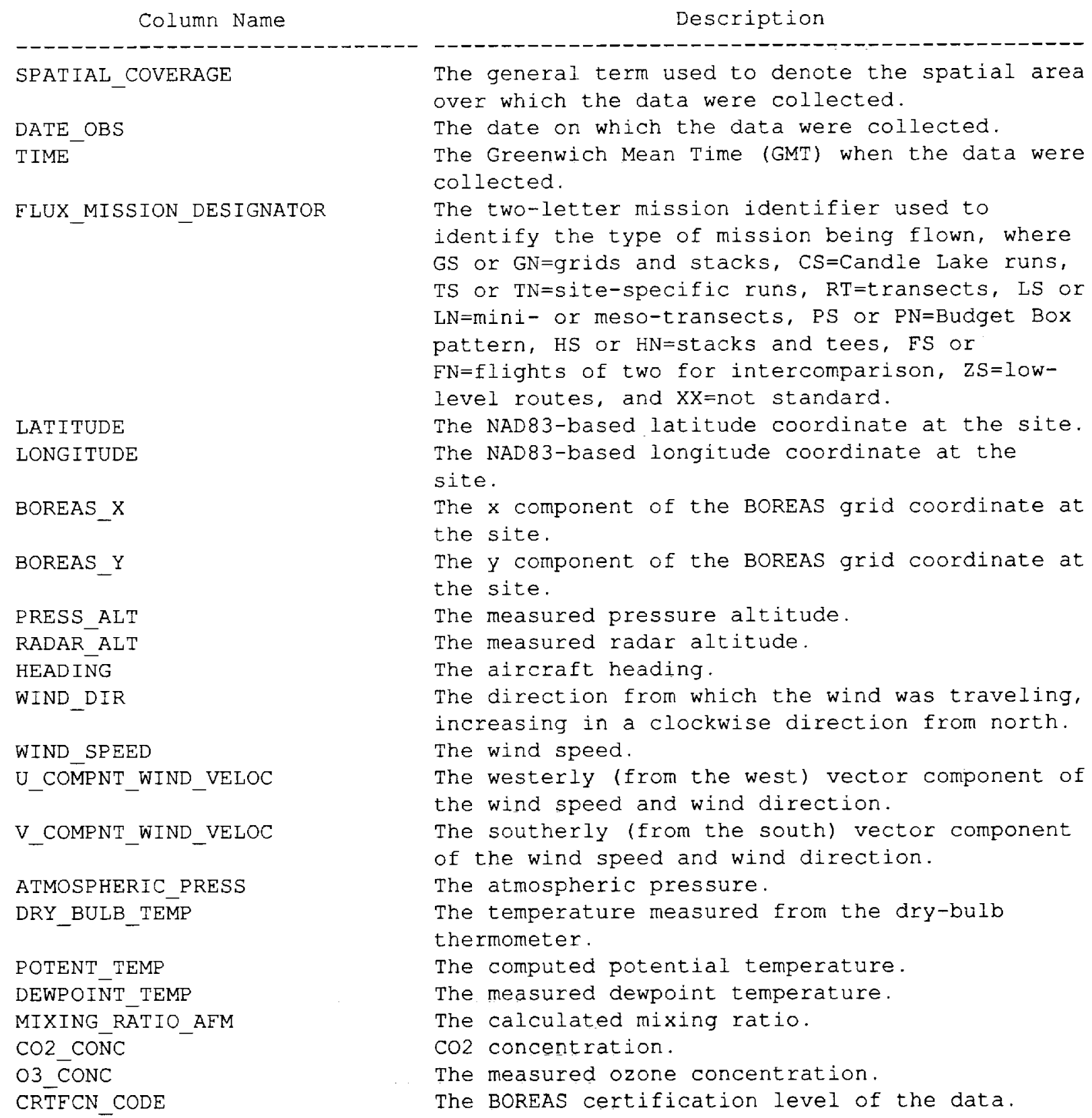

Page 11 
Examples are CPI (Checked by PI), CGR (Certified by Group), PRE (Preliminary), and CPI-??? (CPI but questionable).

REVISION DATE

The most recent date when the information in the referenced data base table record was revised.

\subsubsection{Unit of Measurement}

The measurement units for the parameters contained in the data files on the CD-ROM are:

\begin{tabular}{|c|c|}
\hline Column Name & Units \\
\hline 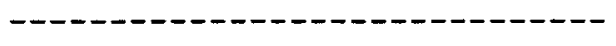 & - - - - - - - - - - - - - - - - \\
\hline SPATIAL_COVERAGE & [none] \\
\hline DATE_OBS & {$[D D-M O N-Y Y]$} \\
\hline TIME & [HHMMSS GMT] \\
\hline FLUX_MISSION_DESIGNATOR & [none] \\
\hline LATITUDE & [degrees] \\
\hline LONGITUDE & [degrees] \\
\hline BOREAS_X & [kilometers] \\
\hline BOREAS_Y & [kilometers] \\
\hline PRESS_ĀLT & [meters] \\
\hline RADAR_ALT & [meters] \\
\hline HEAD ING & [degrees] \\
\hline WIND_DIR & [degrees] \\
\hline WIND_SPEED & [meters] [second^-1] \\
\hline U_COMPNT_WIND_VELOC & [meters] [second^-1] \\
\hline V_COMPNT_WIND_VELOC & [meters] [second^-1] \\
\hline ATMOSPHERIC_PRESS & [kiloPascals] \\
\hline DRY_BULB_TEMP & [degrees Celsius] \\
\hline POTENT TEMP & [degrees Kelvin] \\
\hline DEWPOINT_TEMP & [degrees Celsius] \\
\hline MIXING_RATIO_AFM & [grams of water vapor][kilogram dry air^-1] \\
\hline $\mathrm{CO} 2 \mathrm{CONC}$ & [parts per million] \\
\hline O3_CONC & [parts per billion] \\
\hline CRTFCN_CODE & [none] \\
\hline REVISION_DATE & {$[D D-M O N-Y Y]$} \\
\hline
\end{tabular}

\subsubsection{Data Source}

The sources of the parameter values contained in the data files on the CD-ROM are:

\begin{tabular}{ll}
\multicolumn{1}{c}{ COIUmn Name } & Data Source \\
SPATIAL_COVERAGE & [Assigned by BORIS.] \\
DATE_OBS & [Supplied by Investigator.] \\
TIME & [Supplied by Investigator.] \\
FLUX_MISSION_DESIGNATOR & [Supplied by Investigator.] \\
LATITUDE & [Supplied by Investigator.] \\
LONGITUDE & [Supplied by Investigator.] \\
BOREAS_X & [Supplied by Investigator.] \\
BOREAS_Y & [Supplied by Investigator.] \\
PRESS_ALT & [Supplied by Investigator.] \\
RADAR_ALT & [Supplied by Investigator.] \\
HEADING & [Supplied by Investigator.] \\
WIND_DIR & [Supplied by Investigator.] \\
WIND_SPEED & [Supplied by Investigator.]
\end{tabular}




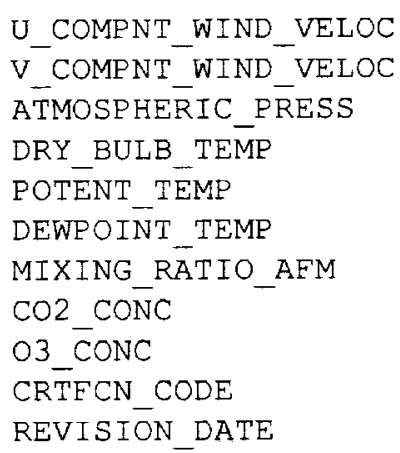

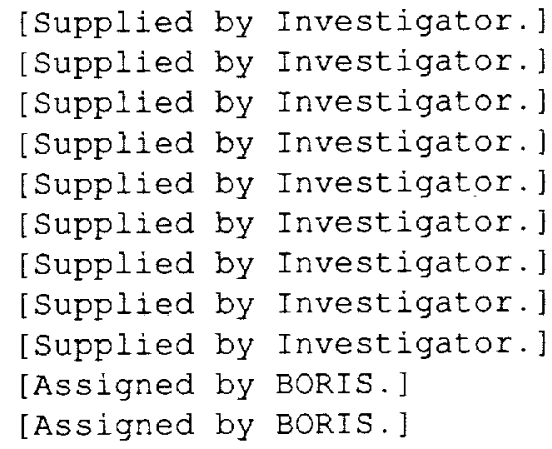

\subsubsection{Data Range}

The following table gives information about the parameter values found in the data files on the CD-ROM.

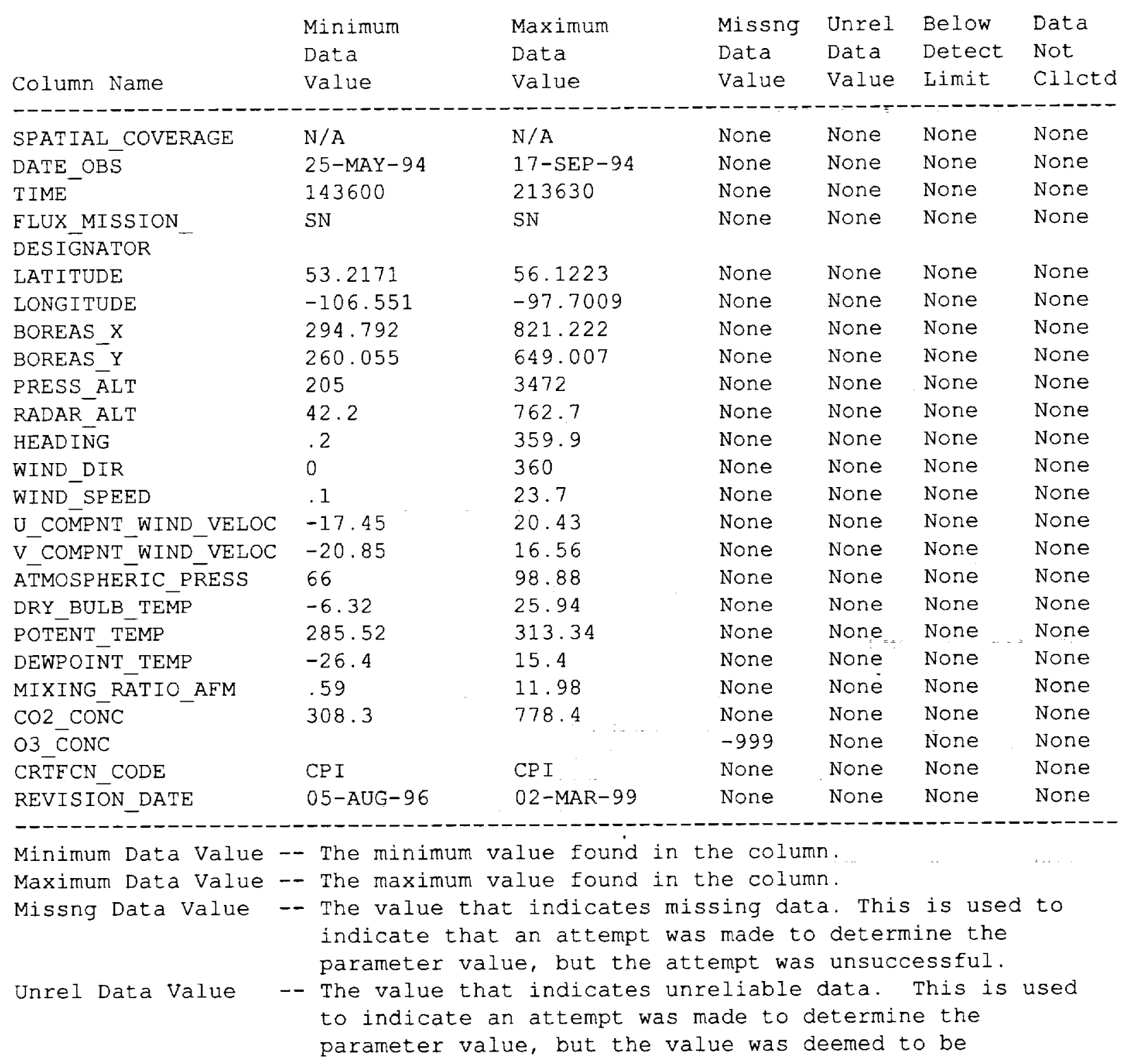




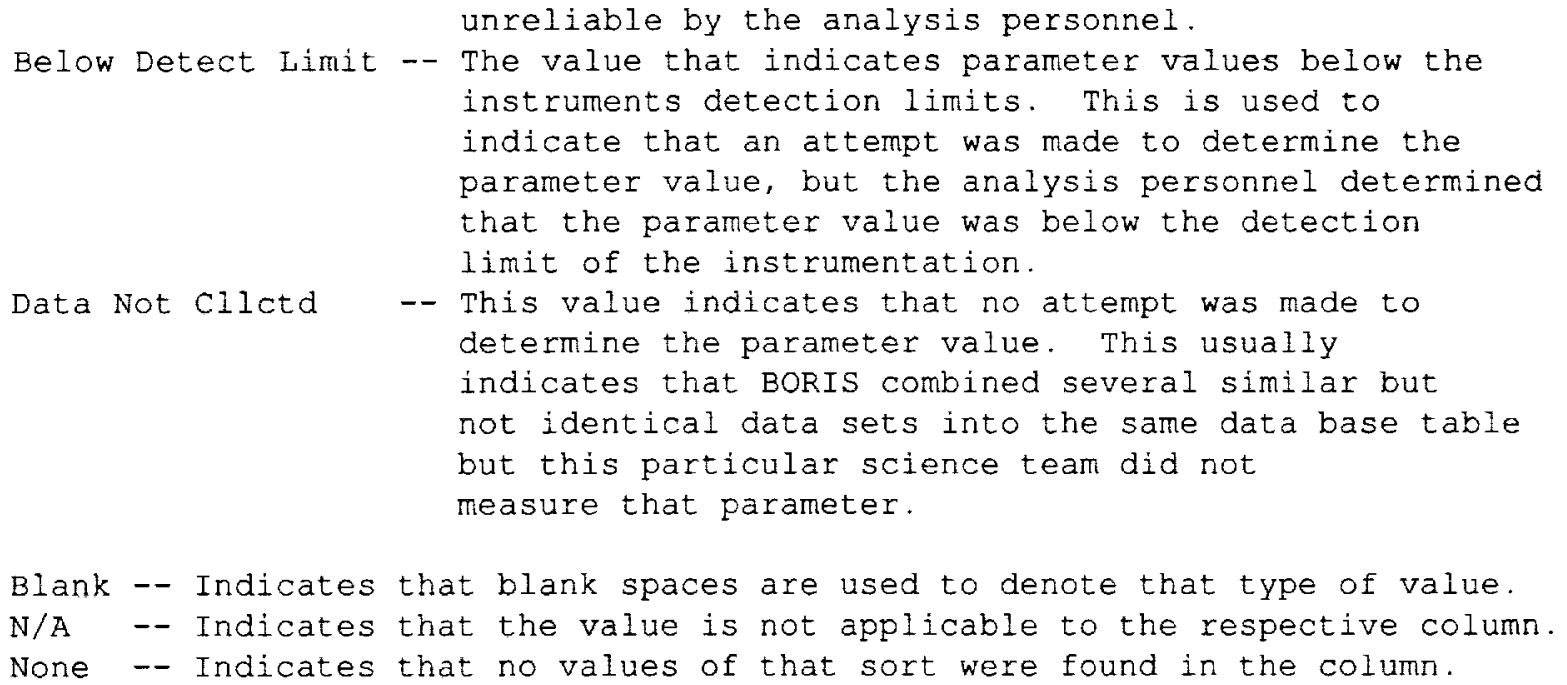

\subsection{Sample Data Record}

The following are wrapped versions of data records from a sample data file on the CD-ROM.

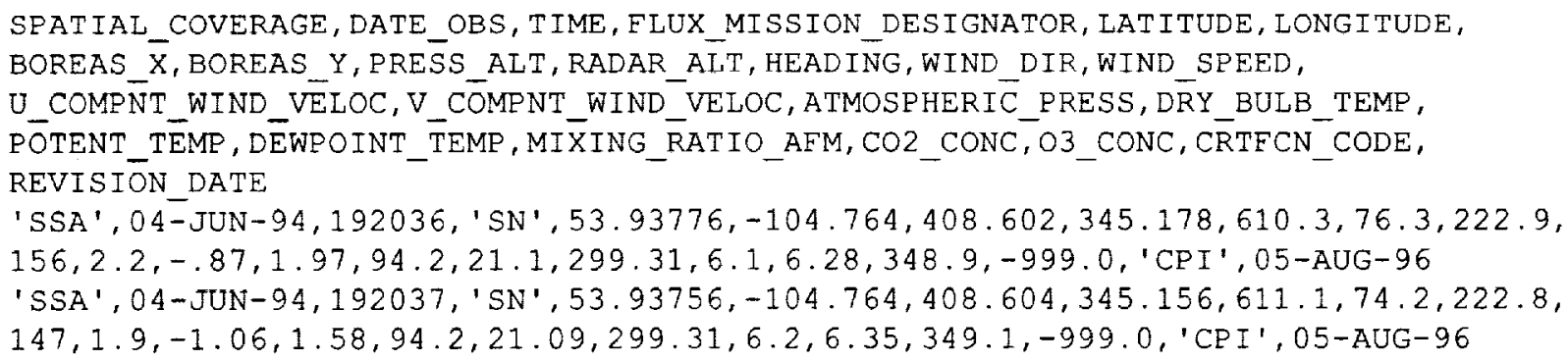

\section{Data Organization}

\subsection{Data Granularity}

The smallest orderable data set available is the one of two files of soundings for a day.

\subsection{Data Format(s)}

The Compact Disk-Read-Only Memory (CD-ROM) files contain ASCII numerical and character fields of varying length separated by commas. The character fields are enclosed with single apostrophe marks. There are no spaces between the fields.

Each data file on the CD-ROM has four header lines of Hyper-Text Markup Language (HTML) code at the top. When viewed with a Web browser, this code displays header information (data set title, location, date, acknowledgments, etc.) and a series of HTML links to associated data files and related data sets. Line 5 of each data file is a list of the column names, and line 6 and following lines contain the actual data. 


\section{Data Manipulations}

\subsection{Formulae}

None.

\subsubsection{Derivation Techniques and Algorithms}

None given.

\subsection{Data Processing Sequence}

\subsubsection{Processing Steps}

- AFM-02 processed the data and sent them to BORIS.

- BORIS staff received the data, made necessary conversions to standard units, and loaded the data into the data base.

- BORIS staff documented the data set and compiled basic statistics about the data.

\subsubsection{Processing Changes}

None.

\subsection{Calculations}

\subsubsection{Special Corrections/Adjustments}

Time lag between $\mathrm{CO}_{2} / \mathrm{H}_{2} \mathrm{O}$ measurements and gust probe:

Due to the geometry of the instrument locations (see Section 4.1.6), there is a significant lag between measurements by the LI-COR device (water vapor and carbon dioxide) and the 3-D winds. Based on instrument placement, external airflow velocities, and internal (sampling tubes) flow velocities, the lag was predicted to be $0.3 \mathrm{sec}$. In contrast, the distance between the gust probe tip and the Friehe temperature probe caused negligible lag between the temperature and wind measurements. Thus, the lag between the temperature and LI-COR measurements should be equivalent to that between the wind and LI-COR measurements. The predicted temperature-LI-COR lag $(0.3 \mathrm{sec})$ was verified by flying the plane several times through the plume from a local power plant, at distances close enough to the source that changes in temperature, water vapor, and $\mathrm{CO}_{2}$ were very abrupt at the plume edges. Thus, prior to any other calculations, the LI-COR data are shifted $0.3 \mathrm{sec}$, to bring those data in sync with the remainder of the data.

\subsubsection{Calculated Variables None given.}

\subsection{Graphs and Plots \\ None.}




\section{Errors}

\subsection{Sources of Error}

See Section 11.2 for a description of instrument limits.

\subsection{Quality Assessment}

An extensive intercomparison of the BOREAS flux aircraft has been written and published by Dobosy et al. (1997). In that text, King Air measurements, including means and variances of all the flux variables, as well as the fluxes themselves, are compared with corresponding values from the Canadian National Research Council (NRC) Twin Otter and the National Center for Atmospheric Research (NCAR) Electra, for multiple wing-to-wing passes at various times during the 1994 experiment. As of this writing, these comparisons are the best available assessments of the overall data quality for the King Air, at least in comparison with similarly instrumented platforms.

\subsubsection{Data Validation by Source}

None.

\subsubsection{Confidence Level/Accuracy Judgment}

The data are considered to be reasonably accurate. See Section 11.2 for description of possible problems.

\subsubsection{Measurement Error for Parameters}

See table in Section 4.1.

\subsubsection{Additional Quality Assessments \\ None.}

\subsubsection{Data Verification by Data Center}

Data were examined for general consistency and clarity.

\section{Notes}

\subsection{Limitations of the Data None given.}

\subsection{Known Problems with the Data}

\section{Vertical velocity measurements:}

Spectral density plots of vertical velocity (w) generally show a fairly well defined inertial subrange, with $-5 / 3$ slope out to about $9 \mathrm{~Hz}$, at which point the effects of the anti-aliasing low-pass filter are evident. Many of the w spectral plots do, however, show a slight "bulge" above the $-5 / 3$ line in the range $0.1-1 \mathrm{~Hz}$. As of this writing (09-Jul-1996), we believe this is an artifact of the postflight calculations. Examples of these spectra can be seen in Dobosy et al. (1997).

\section{High-rate $\mathrm{H}_{2} \mathrm{O}$ measurements (LI-COR 6262):}

The LI-COR 6262 response is described by the manufacturer as being a $90 \%$ response to step-function changes in concentration in $0.1 \mathrm{~s}$. The combination of this characteristic, any along-flow mixing in the sample tubes, and the anti-aliasing filter is evident in the spectral density plots for $\mathrm{H}_{2} \mathrm{O}$ mixing ratio. These plots generally show an inertial subrange (slope $-5 / 3$ ) out to about $2 \mathrm{~Hz}$, at which point the response drops sharply. At $2 \mathrm{~Hz}$, the signal-to-noise ratio (SNR) is usually about $20 \mathrm{~dB}$. Implications of this response for the flux calculations are that the $\mathrm{H}_{2} \mathrm{O}$ fluxes are being resolved only to about $2 \mathrm{~Hz}$ (about $40 \mathrm{~m}$ for typical research airspeeds). 
$\mathrm{CO}_{2}$ measurements (LI-COR 6262):

The response characteristics for $\mathrm{CO}_{2}$ are generally the same as for $\mathrm{H}_{2} \mathrm{O}$, except that the $\mathrm{SNR}$ at 2 $\mathrm{Hz}$ is usually $10 \mathrm{~dB}$ or less. As with $\mathrm{CO}_{2}$, these figures imply that the $\mathrm{CO}_{2}$ fluxes are being resolved only to about $2 \mathrm{~Hz}$ (about $40 \mathrm{~m}$ for typical research airspeeds).

\subsection{Usage Guidance}

None given.

\subsection{Other Relevant Information \\ None.}

\section{Application of the Data Set}

This data set can be used to understand the change in $\mathrm{CO}_{2}$ concentration with altitude, which can in turn be used to infer fluxes.

\section{Future Modifications and Plans}

None given.

\section{Software}

\subsection{Software Description}

None given.

\subsection{Software Access}

None given.

\section{Data Access}

The Wyoming King Air 1994 aircraft sounding data are available from the Earth Observing System Data and Information System (EOSDIS) Oak Ridge National Laboratory (ORNL) Distributed Active Archive Center (DAAC).

\subsection{Contact Information}

For BOREAS data and documentation please contact:

ORNL DAAC User Services

Oak Ridge National Laboratory

P.O. Box 2008 MS-6407

Oak Ridge, TN 37831-6407

Phone: (423) 241-3952

Fax: (423) 574-4665

E-mail: ornldaac@ornl.gov or ornl@eos.nasa.gov

\subsection{Data Center Identification}

Earth Observing System Data and Information System (EOSDIS) Oak Ridge National Laboratory (ORNL) Distributed Active Archive Center (DAAC) for Biogeochemical Dynamics http://www-eosdis.ornl.gov/ [Internet Link]. 


\subsection{Procedures for Obtaining Data}

Users may obtain data directly through the ORNL DAAC online search and order system [http://www-eosdis.ornl.gov/] and the anonymous FTP site [ftp://www-eosdis.ornl.gov/data/] or by contacting User Services by electronic mail, telephone, fax, letter, or personal visit using the contact information in Section 15.1.

\subsection{Data Center Status/Plans}

The ORNL DAAC is the primary source for BOREAS field measurement, image, GIS, and hardcopy data products. The BOREAS CD-ROM and data referenced or listed in inventories on the CD-ROM are available from the ORNL DAAC.

\section{Output Products and Availability}

\subsection{Tape Products}

Not applicable.

\subsection{Film Products}

Not applicable.

\subsection{Other Products}

These data are available on the BOREAS CD-ROM series.

\section{References}

\subsection{Platform/Sensor/Instrument/Data Processing Documentation See references listed in Section 17.2.}

\subsection{Journal Articles and Study Reports}

Baijards, S.A.M. and R.D. Kelly. 1996. Conditional sampling applied to BOREAS aircraft data. Preprints, 22nd Conf. on Agric. and Forest Meteor., 28 Jan. - 2 Feb. 1996, Atlanta, GA.

Baijards, S.A.M., S.O. Ogunjemiyo, R.D. Kelly, and P.H. Schuepp. 1996. Preliminary analysis of dual aircraft boundary layer grid flux. Submitted to Journal of Geophysical Research.

Betts, A.K., R.L. Desjardins, and J.I. MacPherson. 1990a. Boundary layer heat and moisture budgets from FIFE. AMS Symposium on First ISLSCP Field Experiment (FIFE), 70th AMS Annual Meeting, Feb. 5-9, 1990, Anaheim, CA.

Betts, A.K., R.L. Desjardins, J.I. MacPherson, and R.D. Kelly. 1989. Boundary layer heat and moisture budgets. Spring 1989 meeting of Amer. Geophys. Union, May 7-11, 1989, Baltimore.

Betts, A.K., R.L. Desjardins, J.I. MacPherson, and R.D. Kelly. 1990b. Boundary-Layer heat and moisture budgets from FIFE. Boundary-Layer Meteorology 50(1-4): 109-138.

Dobosy, R.J., T.L. Crawford, J.I. MacPherson, R.L. Desjardins, R.D. Kelly, S.P. Oncley, and D.H. Lenschow. 1997. Intercomparison among four flux aircraft at BOREAS in 1994. Joumal of Geophysical Research 102(D24): 29,101-29,111.

Kelly, R.D., J.I. MacPherson, R.J. Dobosy, and T.L. Crawford. 1996. BOREAS 1994 intercomparison among three flux aircraft. Preprints, 22nd Conf. on Agric. and Forest Meteor., 28 Jan. - 2 Feb. 1996, Atlanta, GA. 
Lenschow, D.H. (ed.). 1986. Probing the Atmospheric Boundary Layer, Amer. Meteor. Soc., Boston.

McDermott, M.L. and R.D. Kelly. 1995. Fluxes over a heterogeneous forest. Preprints 11 th Symposium on Bound. Layers and Turbulence, Charlotte, NC, 27-31 March, 1995.

McDermott, M.L. and R.D. Kelly. 1996. Variation of boundary layer fluxes with heterogeneous surface vegetation and seasonal change. Submitted to Journal of Geophysical Research.

Newcomer, J., D. Landis, S. Conrad, S. Curd, K. Huemmrich, D. Knapp, A. Morrell, J. Nickeson, A. Papagno, D. Rinker, R. Strub, T. Twine, F. Hall, and P. Sellers, eds. 2000. Collected Data of The Boreal Ecosystem-Atmosphere Study. NASA. CD-ROM.

Sellers, P. and F. Hall. 1994. Boreal Ecosystem-Atmosphere Study: Experiment Plan. Version 1994-3.0, NASA BOREAS Report (EXPLAN 94).

Sellers, P. and F. Hall. 1996. Boreal Ecosystem-Atmosphere Study: Experiment Plan. Version 1996-2.0, NASA BOREAS Report (EXPLAN 96).

Sellers, P., F. Hall, and K.F. Huemmrich. 1996. Boreal Ecosystem-Atmosphere Study: 1994 Operations. NASA BOREAS Report (OPS DOC 94).

Sellers, P., F. Hall, and K.F. Huemmrich. 1997. Boreal Ecosystem-Atmosphere Study: 1996 Operations. NASA BOREAS Report (OPS DOC 96).

Sellers, P., F. Hall, H. Margolis, B. Kelly, D. Baldocchi, G. den Hartog, J. Cihlar, M.G. Ryan, B. Goodison, P. Crill, K.J. Ranson, D. Lettenmaier, and D.E. Wickland. 1995. The boreal ecosystem-atmosphere study (BOREAS): an overview and early results from the 1994 field year. Bulletin of the American Meteorological Society. 76(9):1549-1577.

Sellers, P.J., F.G. Hall, R.D. Kelly, A. Black, D. Baldocchi, J. Berry, M. Ryan, K.J. Ranson, P.M. Crill, D.P. Lettenmaier, H. Margolis, J. Cihlar, J. Newcomer, D. Fitzjarrald, P.G. Jarvis, S.T. Gower, D. Halliwell, D. Williams, B. Goodison, D.E. Wickland, and F.E. Guertin. 1997. BOREAS in 1997: Experiment Overview, Scientific Results and Future Directions. Journal of Geophysical Research 102(D24): 28,731-28,770.

\subsection{Archive/DBMS Usage Documentation None.}




\section{Glossary of Terms}

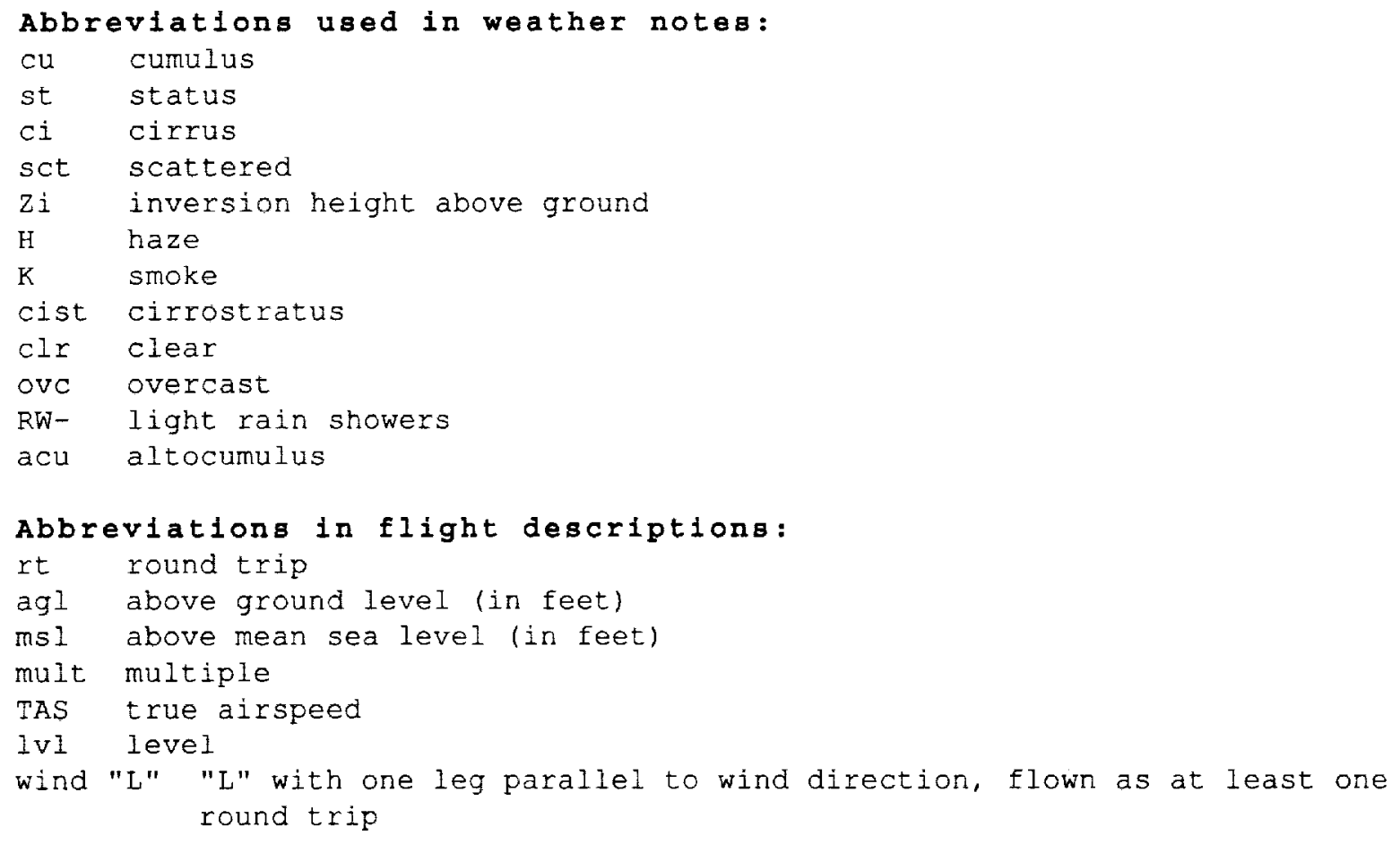

\section{List of Acronyms}

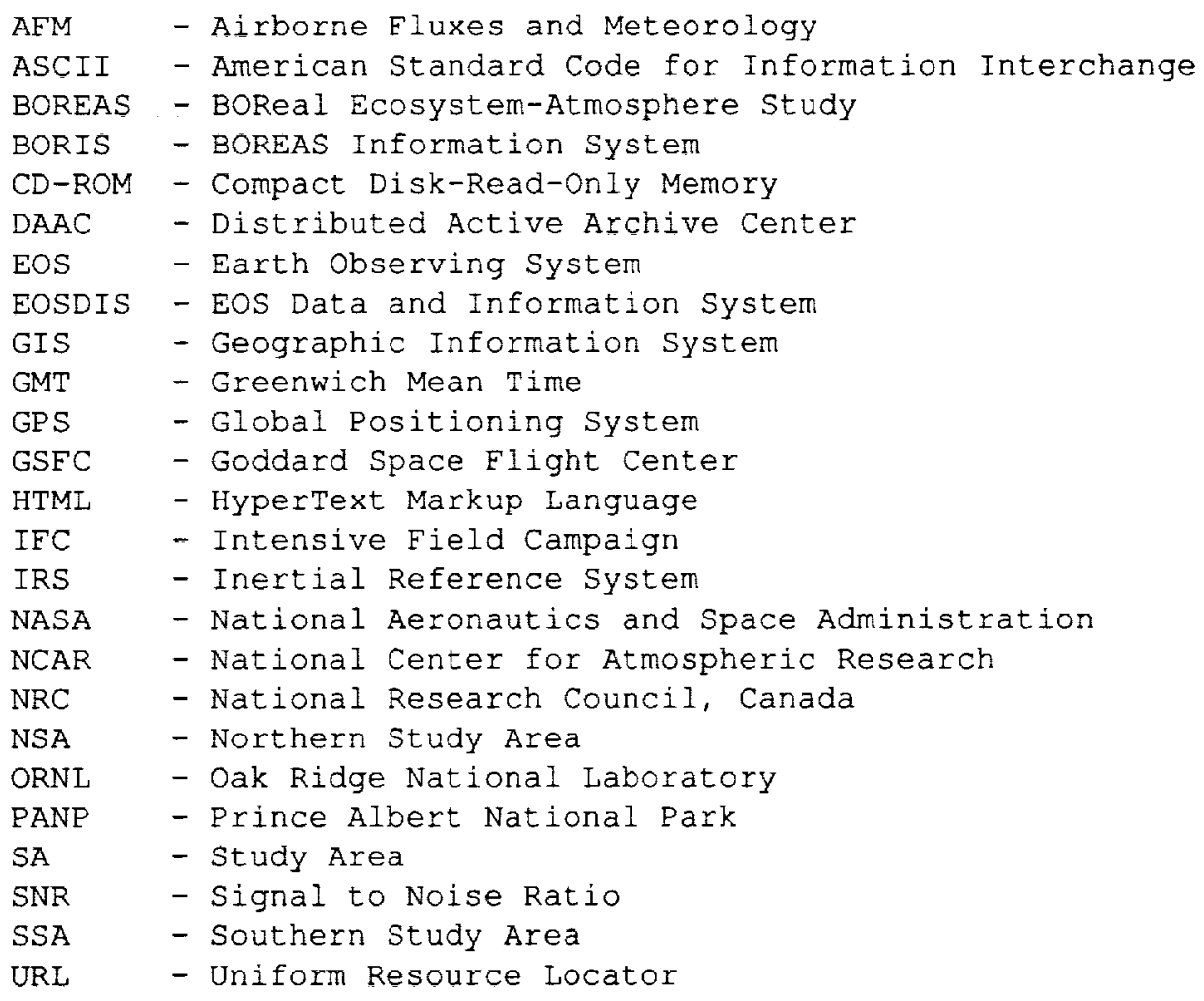




\section{Document Information}

20.1 Document Revision Date

Written: 09-Jul-1996

Last Updated: 08-Oct-1999

\subsection{Document Review Date(s)}

BORIS Review: 30-Jun-1999

Science Review:

\subsection{Document ID}

\subsection{Citation}

When using these data, please contact the personnel listed in Section 2.3 as well as citing relevant papers in Section 17.2.

If using data from the BOREAS CD-ROM series, also reference the data as:

Kelly, R.D., "Airbome Investigation of Biosphere-Atmosphere Interactions over the Boreal

Forest." In Collected Data of The Boreal Ecosystem-Atmosphere Study. Eds. J. Newcomer, D.

Landis, S. Conrad, S. Curd, K. Huemmrich, D. Knapp, A. Morrell, J. Nickeson, A. Papagno, D.

Rinker, R. Strub, T. Twine, F. Hall, and P. Sellers. CD-ROM. NASA, 2000.

Also, cite the BOREAS CD-ROM set as:

Newcomer, J., D. Landis, S. Conrad, S. Curd, K. Huemmrich, D. Knapp, A. Morrell, J.

Nickeson, A. Papagno, D. Rinker, R. Strub, T. Twine, F. Hall, and P. Sellers, eds. Collected Data of The Boreal Ecosystem-Atmosphere Study. NASA. CD-ROM. NASA, 2000.

\subsection{Document Curator}

\subsection{Document URL}


Public reporting burden for this collection of information is estimated to average 1 hour per response, including the time for reviewing instructions, searching existing data sources, gathering and maintalning the data needed, and completing and revlewing the collection of information. Send comments regarding this burden estimate or any other aspect of this collection of information, including suggestions for reducing this burden, to Washington Headquarters Servlces, Directorate for information Operations and Reports, 1215 Jefferson Davis Highway, Suite 1204, Arlington, VA 22202-4302, and to the Office of Mariagement and Budget, Paperwork Reduction Project (0704-0188), Washington, OC 20503.
1. AGENCY USE ONLY (Leave blank)
2. REPORT DATE
June 2000

\section{REPORT TYPE AND DATES COVERED}
Technical Memorandum

4. TITLE AND SUBTITLE

Technical Report Series on the Boreal Ecosystem-Atmosphere Study (BOREAS)

BOREAS AFM-02 Wyoming King Air 1994 Aircraft Sounding Data

923

6. AUTHOR(S)

Robert D. Kelly

Forrest G. Hall and David E. Knapp, Editors

7. PERFORMING ORGANIZATION NAME(S) AND ADDRESS (ES)

Goddard Space Flight Center

Greenbelt, Maryland 20771

RTOP: 923-462-33-01

9. SPONSORING / MONITORING AGENCY NAME(S) AND ADDRESS (ES)

National Aeronautics and Space Administration

Washington, DC 20546-0001

8. PEFORMING ORGANIZATION

REPORT NUMBER

$2000-03136-0$

10. SPONSORING / MONITORING AGENCY REPORT NUMBER

TM-2000-209891

Vol. 3

\section{SUPPLEMENTARY NOTES}

R.D. Kelly: University of Wyoming; D.E. Knapp: Raytheon ITSS

\section{2a. DISTRIBUTION / AVAILABILITY STATEMENT}

12b. DISTRIBUTION CODE

Unclassified-Unlimited

Subject Category: 43

Report available from the NASA Center for AeroSpace Information, 7121 Standard Drive, Hanover, MD 21076-1320. (301) 621-0390.

\section{ABSTRACT (Maximum 200 words)}

The BOREAS AFM-2 team used the University of Wyoming King Air aircraft during IFCs 1, 2, and 3 in 1994 to collected pass-by-pass fluxes (and many other statistics) for the large number of level (constant altitude), straight-line passes used in a variety of flight patterns over the SSA and NSA and areas along the transect between these study areas. The data described here form a second set, namely soundings that were incorporated into nearly every research flight by the King Air in 1994. These soundings generally went from near the surface to above the inversion layer. Most were flown immediately after takeoff or immediately after finishing the last flux pattern of that particular day's flights. The parameters that were measured include wind direction, wind speed, west wind component (u), south wind component $(\mathrm{v})$, static pressure, air dry bulb temperature, potential temperature, dewpoint, temperature, water vapor mixing ratio, and $\mathrm{CO}_{2}$ concentration. Data on the aircraft's location, attitude, and altitude during data collection are also provided. These data are stored in tabular ASCII files.

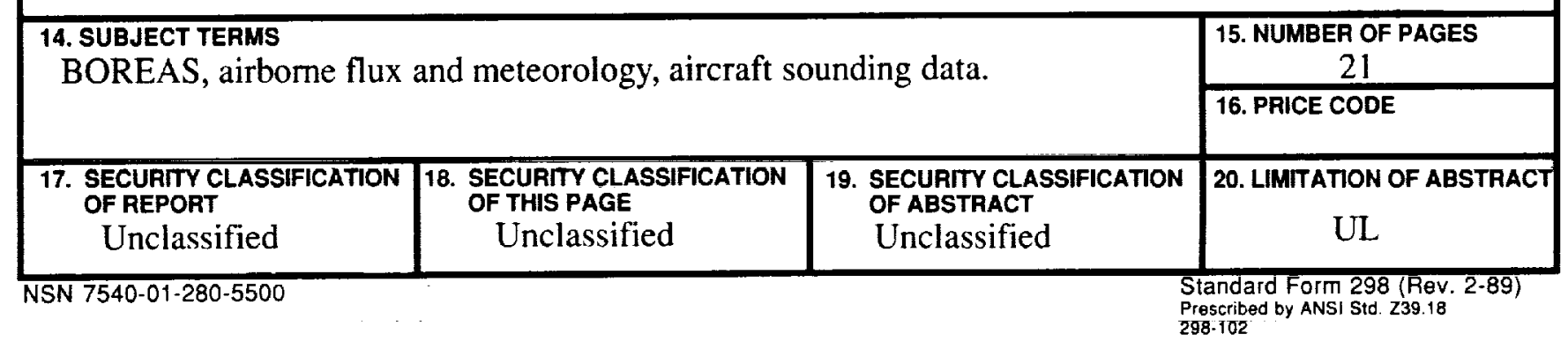

